\title{
Effects of short-term nitrogen and phosphorus addition on leaf stoichiometry of a dominant alpine grass
}

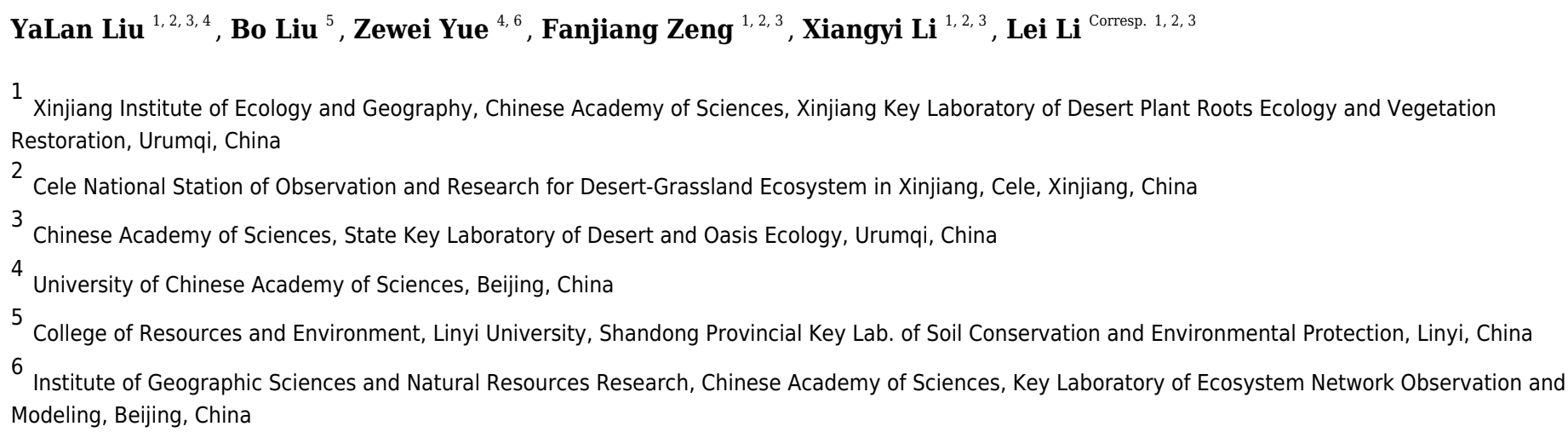

The effects of increasing nitrogen $(\mathrm{N})$ and phosphorus $(\mathrm{P})$ deposition on the nutrient stoichiometry of soil and plant are gaining improving recognition. However, whether and how the responses of $\mathrm{N}$ cycle coupled with $\mathrm{P}$ of the soil-plant system to external $\mathrm{N}$ and $\mathrm{P}$ deposition in alpine grassland is still unclear. A short-term external $\mathrm{N}$ and $\mathrm{P}$ addition experiment was conducted in an alpine grazing grassland in the KunLun Mountain to explore the effects of short-term $\mathrm{N}$ and $\mathrm{P}$ addition on the nutrient stoichiometry in soil and plant. Different rates of $\mathrm{N}$ addition (ranging from $0.5 \mathrm{~g} \mathrm{~N} \mathrm{~m}^{-2} \mathrm{yr}^{-1}$ to $24 \mathrm{~g} \mathrm{~N} \mathrm{~m}^{-2} \mathrm{yr}^{-1}$ ) and $\mathrm{P}$ addition (ranging from $0.05 \mathrm{~g} \mathrm{~N} \mathrm{~m}^{-2} \mathrm{yr}^{-1}$ to $3.2 \mathrm{~g} \mathrm{P} \mathrm{m}^{-2} \mathrm{yr}^{-1}$ ) were supplied, and the soil available N, P, leaf N and P stoichiometry of Seriphidium rhodanthum which dominant in the alpine ecosystem were measured. Results showed that $\mathrm{N}$ addition increased soil inorganic $N$, leaf $C$, leaf $N$, and leaf $N: P$ ratio but decreased soil available $P$ and leaf $C: P$. Furthermore, $\mathrm{P}$ addition increased soil available $\mathrm{P}$, leaf $\mathrm{P}$, soil inorganic $\mathrm{N}$, leaf $\mathrm{N}$, and leaf $\mathrm{C}$ and reduced leaf $C: N, C: P$, and $N: P$ ratios. Leaf $N: P$ was positively related to $N$ addition gradient. Leaf $\mathrm{C}: \mathrm{P}$ and leaf $\mathrm{N}: \mathrm{P}$ were significantly negatively related to $\mathrm{P}$ addition gradient. Although external $\mathrm{N}$ and $\mathrm{P}$ addition changed the value of leaf $\mathrm{N}: \mathrm{P}$, the ratio was always lower than 16 in all treatments. The influences of $P$ addition on soil and plant mainly caused the increase in soil available $\mathrm{P}$ concentration. In addition, the $\mathrm{N}$ and $\mathrm{P}$ cycles in the soil-plant system were tightly coupled in $\mathrm{P}$ addition but decoupled in $\mathrm{N}$ addition condition. The nutrient stoichiometry of soil and leaf responded differently to continuous $\mathrm{N}$ and $\mathrm{P}$ addition gradients. These data suggested that the alpine grazing grassland was limited by $\mathrm{P}$ rather than $\mathrm{N}$ due to long-term $\mathrm{N}$ deposition and uniform fertilization. Moreover, 
increasing $\mathrm{P}$ addition alleviated $\mathrm{P}$ limitation. Therefore, the imbalanced $\mathrm{N}$ and $\mathrm{P}$ input could change the strategy of nutrient use of the grass and then change the rates of nutrient cycling in the alpine grassland ecosystem in the future. 
1 Effects of short-term nitrogen and phosphorus addition on leaf stoichiometry of a dominant alpine grass

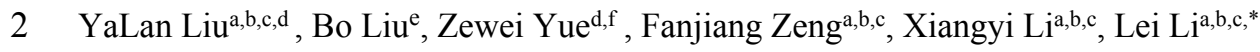

${ }^{a}$ Xinjiang Key Laboratory of Desert Plant Roots Ecology and Vegetation Restoration, Xinjiang Institute of Ecology and Geography, Chinese Academy of Sciences, Urumqi, 830011, China

${ }^{b}$ Cele National Station of Observation and Research for Desert-Grassland Ecosystem in Xinjiang, Cele, 848300, Xinjiang, China

${ }^{c}$ State Key Laboratory of Desert and Oasis Ecology, Chinese Academy of Sciences, Urumqi, China

${ }^{d}$ University of Chinese Academy of Sciences, Beijing, 100049, China

${ }^{e}$ Shandong Provincial Key Lab. of Soil Conservation and Environmental Protection, College of Resources and Environment, Linyi University, Linyi, 276000, China

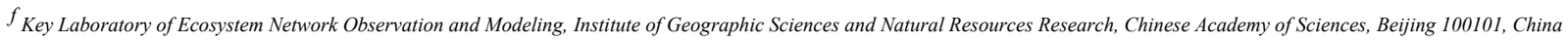

${ }^{*}$ Corresponding author. Xinjiang Institute of Ecology and Geography, CAS 40-3 South Beijing Rd., Urumqi, Xinjiang, 830011, China. E-m il address: lilei@ms.xjb.ac.cn (L. Li).

\section{Abstract}

The effects of increasing nitrogen $(\mathrm{N})$ and phosphorus $(\mathrm{P})$ deposition on the nutrient stoichiometry of soil and plant are gaining improving recognition. However, whether and how the responses of $\mathrm{N}$ cycle coupled with $\mathrm{P}$ of the soilplant system to external $\mathrm{N}$ and $\mathrm{P}$ deposition in alpine grassland is still unclear. A short-term external $\mathrm{N}$ and $\mathrm{P}$ addition experiment was conducted in an alpine grazing grassland in the KunLun Mountain to explore the effects of short-term $\mathrm{N}$ and $\mathrm{P}$ addition on the nutrient stoichiometry in soil and plant. Different rates of $\mathrm{N}$ addition (ranging from $0.5 \mathrm{~g} \mathrm{~N}$ $\mathrm{m}^{-2} \mathrm{yr}^{-1}$ to $24 \mathrm{~g} \mathrm{~N} \mathrm{~m}^{-2} \mathrm{yr}^{-1}$ ) and $\mathrm{P}$ addition (ranging from $0.05 \mathrm{~g} \mathrm{~N} \mathrm{~m}^{-2} \mathrm{yr}^{-1}$ to $3.2 \mathrm{~g} \mathrm{P} \mathrm{m}^{-2} \mathrm{yr}^{-1}$ ) were supplied, and the soil available N, P, leaf Nand P stoichiometry of Seriphidium rhodanthum which dominant in the alpine ecosystem were measured. Results showed that $\mathrm{N}$ addition increased soil inorganic $\mathrm{N}$, leaf $\mathrm{C}$, leaf $\mathrm{N}$, and leaf $\mathrm{N}: \mathrm{P}$ ratio but decreased soil available $\mathrm{P}$ and leaf C:P. Furthermore, $\mathrm{P}$ addition increased soil available $\mathrm{P}$, leaf $\mathrm{P}$, soil inorganic N, leaf $\mathrm{N}$, and leaf $\mathrm{C}$ and reduced leaf $\mathrm{C}: \mathrm{N}, \mathrm{C}: \mathrm{P}$, and $\mathrm{N}: \mathrm{P}$ ratios. Leaf $\mathrm{N}: \mathrm{P}$ was positively related to $\mathrm{N}$ addition gradient. Leaf $\mathrm{C}: \mathrm{P}$ and leaf $\mathrm{N}: \mathrm{P}$ were significantly negatively related to $\mathrm{P}$ addition gradient. Although external $\mathrm{N}$ and $\mathrm{P}$ addition changed the value of leaf $\mathrm{N}: \mathrm{P}$, the ratio was always lower than 16 in all treatments. The influences of $\mathrm{P}$ addition on soil and plant mainly caused the increase in soil available $\mathrm{P}$ concentration. In addition, the $\mathrm{N}$ and $\mathrm{P}$ cycles in the soilplant system were tightly coupled in $\mathrm{P}$ addition but decoupled in $\mathrm{N}$ addition condition. The nutrient stoichiometry of soil and leaf responded differently to continuous $\mathrm{N}$ and $\mathrm{P}$ addition gradients. These data suggested that the alpine grazing grassland was limited by $\mathrm{P}$ rather than $\mathrm{N}$ due to long-term $\mathrm{N}$ deposition and uniform fertilization. Moreover, increasing $\mathrm{P}$ addition alleviated $\mathrm{P}$ limitation. Therefore, the imbalanced $\mathrm{N}$ and $\mathrm{P}$ input could change the strategy of nutrient use of the grass and then change the rates of nutrient cycling in the alpine grassland ecosystem in the future.

Keywords: nutrient addition, leaf nutrient concentration, leaf stoichiometry, alpine grazing grassland

\section{Introduction}

Nitrogen $(\mathrm{N})$ and phosphorus $(\mathrm{P})$ are major limiting elements that determine the plant fixation of carbon $(\mathrm{C})$ (Sardans et al., 2012; Mo et al., 2015; Wang et al., 2020), and the balance of $\mathrm{N}$ and $\mathrm{P}$ supply is crucial for the terrestrial ecosystems to maintain stability ( $\mathrm{Li}$ et al., 2020; Yang et al., 2018). However, previous studies have reported that the amount of $\mathrm{N}$ deposition to the ecosystems increased from $32 \mathrm{Tg}$ year ${ }^{-1}$ to $200 \mathrm{Tg}$ year ${ }^{-1}$ (Lamarque et al., 2013), while 
and increasing external $\mathrm{N}$ and $\mathrm{P}$ supply induced by human activities and global change profoundly exert influences on the nutrient cycle between soil and plant and then alter the structure and functions of an ecosystem (Galloway et al., 1996; Bennett et al., 2001; Zhu et al., 2016). Many simulated N and P addition experiments were conducted widely on the global scale to explore how the imbalance of $\mathrm{N}$ and $\mathrm{P}$ deposition influences the $\mathrm{N}$ and $\mathrm{P}$ dynamics of the soilplant system (Lü et al. 2016; Deng et al., 2017). Many studies have reported that terrestrial ecosystems limited by N have been shifted to limited by $\mathrm{P}$ or co-limited by $\mathrm{N}$ and $\mathrm{P}$ based on the analysis of soil-plant nutrient stoichiometry (Tian and Niu 2015; Peñuelas et al., 2013).

Leaf nutrient concentration was a widely used index of nutrient limitation and the growth of plants (Vitousek 1998; Wright et al., 2005). Leaf nutrient concentration is generally regarded as related to soil nutrient availability (Zhang et al., 2017; Li et al., 2016a). Positive relationships between leaf nutrients concentration and soil nutrients availability were also widely observed (Chapin et al., 1986; Chen et al., 2015). How N addition influences N cycle and how P addition influences $\mathrm{P}$ cycle homogeneously between soil and plants have been studied widely to predict the influences on the ecosystem of N and P deposition (Wright et al., 2005; Ritchie 2000; Li et al., 2021). For example, Yang et al. (2018) reported that $\mathrm{P}$ addition significantly and positively increased leaf and soil P concentrations. Yuan and Chen (2015) reported that $\mathrm{N}$ addition improved leaf $\mathrm{N}$ and decreased leaf nutrient resorption efficiency by increasing soil $\mathrm{N}$ concentration in some N-limited ecosystems. However, studies on how $\mathrm{N}$ concentrations in soil and plants respond to $\mathrm{P}$ addition and $\mathrm{P}$ concentrations respond to $\mathrm{N}$ addition are lacking and inconsistent (Zhang et al., 2017; Li et al., 2020). The effects of $\mathrm{N}$ addition on leaf $\mathrm{P}$ concentration were demonstrated to be neutral (Chen et al., 2015; Tian and Niu 2015; Peñuelas et al., 2013), positive (Song et al., 2020), and negative (Sardans et al., 2015). Deng et al. (2017) found that $\mathrm{N}$ addition decreased leaf $\mathrm{P}$ concentration in tropical forests in a meta-analysis. Liu et al (2021) reported that short term $\mathrm{P}$ addition alone did not affect soil respiration, but augments the effects of $\mathrm{N}$ addition on soil respiration. However, some studies have also shown that $\mathrm{N}$ addition exerted no significance on leaf $\mathrm{P}$ concentration in tropical forests. The inconsistent results implied that the influences of imbalanced nutrient supply on patterns of coupling relationship between $\mathrm{N}$ and $\mathrm{P}$ are more complex than expected and they need to be further investigated.

External nutrient supply could reorder plant C, N, P, and other nutrient allocation due to promoting plant growth and other homeostatic abilities (Tian et al., 2018; You et al., 2018). Leaf C:N:P could indicate the growth of plants to a greater extent ( $\mathrm{Li}$ et al., 2021; Chen et al., 2015). Moreover, leaf N:P ratio was widely used to show and predict ecosystem limitation (Güsewell 2004; Zhang et al., 2017; Chen et al., 2015), Leaf N:P always increases with N addition (Fujita et al., 2010), implying that $\mathrm{N}$ limitation was alleviated and $\mathrm{P}$ limitation was aggravated. However, the ratio has some restrictions. Koerselman and Meuleman (1996) reported that N:P ratios of $<14$ and $>16$ imply N and P limitation, respectively. Whereas Güsewell (2004) showed that 10 and 20 were the threshold values for $\mathrm{N}$ and $\mathrm{P}$ limitations in the terrestrial ecosystem from a meta-analysis basis. Moreover, present studies confirmed that the critical values of N:P ratios are determined by species, the ecosystem nutrient limitation type, and other factors (Oheimb et al., 2010; $\mathrm{Xu}$ et al., 2014). Therefore, to understand the mechanism of $\mathrm{N}$ and $\mathrm{P}$ coupled with respond to $\mathrm{N}$ and $\mathrm{P}$ addition, exploring how the leaf $\mathrm{N}: \mathrm{P}$ ratio dominating plants in different ecosystems respond to nutrient addition is necessary.

Alpine grassland plays a crucial role in terrestrial ecosystems, which was almost regarded as limited by $\mathrm{N}$ or co-limited by $\mathrm{N}$ and P (Xu et al., 2014; Li et al., 2016b). Some studies reported that climate change and human activity (e.g. fertilization $\mathrm{N}$ ) brought more uncertainties factors, which lead to $\mathrm{N}$ limitation being shifted to $\mathrm{P}$ limitation in grassland 
(Peñuelas et al., 2012; Sardans et al., 2012). However, previous studies about the effect of fertilization on grassland ecosystem limitation mostly focused on the temperate grassland ecosystem, but the alpine grazing grassland has been ignored. These hypotheses have not been tested in alpine grassland (Sardans et al., 2012).

Here, a simulated external nutrient input experiment was conducted in an alpine grassland, which is an important pasture of Kunlun Mountain in Xinjiang Province (Fang et al., 2013). Based on the aforementioned information, we hypothesize 1) leaf and soil nutrient concentration could improve with increasing $\mathrm{N}$ and $\mathrm{P}$ addition; 2) leaf $\mathrm{N}$ and $\mathrm{P}$ are linked when responding to $\mathrm{N}$ and $\mathrm{P}$ addition; 3 ) the alpine grassland limited by $\mathrm{N}$ or co-limited by $\mathrm{N}$ and $\mathrm{P}$;. And soil nutrient availability, leaf nutrient concentrations, and leaf stoichiometry after short multi-level $\mathrm{N}$ and $\mathrm{P}$ addition experiments were explored to quantify these hypothesizes.

\section{Materials and methods}

\section{Study region and experimental design}

This study was carried out in an alpine grassland in the Kunlun Mountain, Xinjiang Province $\left(80^{\circ} 35^{\prime} 08^{\prime \prime}\right.$ E, $36^{\circ} 08^{\prime} 02^{\prime \prime}$ $\mathrm{N}$ ) in 2017. The altitude of this region is $3236 \mathrm{~m}$. In 2017 and 2018 , the mean annual temperature was $3.2^{\circ} \mathrm{C}$, and it ranges from $-7.8{ }^{\circ} \mathrm{C}$ in December to $13.2{ }^{\circ} \mathrm{C}$ in July. The mean precipitation is $482 \mathrm{~mm}$, mostly occurring from May to September. Long-term meteorological data in this site was deficient. The period of herbed of this site was more than 20 years, and Seriphidium rhodanthum is the main dominant grass in this alpine grassland covers more than $70 \%$ of the total aboveground biomass (Li et al., 2020).

The topographic condition in the research site shows uniform. A wide gradient $\mathrm{N}$ and $\mathrm{P}$ addition experiment was conducted, including the following: $\mathrm{CK}$ (control); $\mathrm{N} 1\left(0.5 \mathrm{~g} \mathrm{~N} \mathrm{~m}^{-2} \mathrm{yr}^{-1}\right), \mathrm{N} 2\left(1 \mathrm{~g} \mathrm{~N} \mathrm{~m}^{-2} \mathrm{yr}^{-1}\right), \mathrm{N} 3\left(2 \mathrm{~g} \mathrm{~N} \mathrm{~m}^{-2} \mathrm{yr}^{-1}\right), \mathrm{N} 4$ (3 $\left.\mathrm{g} \mathrm{N} \mathrm{m}^{-2} \mathrm{yr}^{-1}\right)$, N5 $\left(6 \mathrm{~g} \mathrm{~N} \mathrm{~m}^{-2} \mathrm{yr}^{-1}\right), \mathrm{N} 6\left(12 \mathrm{~g} \mathrm{~N} \mathrm{~m}^{-2} \mathrm{yr}^{-1}\right)$ and $\mathrm{N} 7\left(24 \mathrm{~g} \mathrm{~N} \mathrm{~m}^{-2} \mathrm{yr}^{-1}\right)$ for N addition of urea, and P1 (0.05 $\left.\mathrm{g} \mathrm{P} \mathrm{m}^{-2} \mathrm{yr}^{-1}\right)$, P2 (0.1 $\left.\mathrm{g} \mathrm{P} \mathrm{m}^{-2} \mathrm{yr}^{-1}\right)$, P3 (0.2 $\left.\mathrm{g} \mathrm{P} \mathrm{m}^{-2} \mathrm{yr}^{-1}\right)$, P4 (0.4 $\left.\mathrm{g} \mathrm{P} \mathrm{m}^{-2} \mathrm{yr}^{-1}\right)$, P5 (0.8 $\left.\mathrm{g} \mathrm{P} \mathrm{m}^{-2} \mathrm{yr}^{-1}\right)$, P6 (1.6 g $\left.\mathrm{P} \mathrm{m}^{-2} \mathrm{yr}^{-1}\right)$, and $\mathrm{P} 7\left(3.2 \mathrm{~g} \mathrm{P} \mathrm{m}^{-2} \mathrm{yr}^{-1}\right)$ for $\mathrm{P}$ addition of $\mathrm{KH}_{2} \mathrm{PO}_{4}$. The application rates were adopted from the study of Yue et al. (2016), which was conducted in Bayanbulak, Xinjiang. The treatments adopted a completely randomized design, and each has four replicate plots (total of 60 plots). Every plot was $3 \mathrm{~m} \times 2 \mathrm{~m}$ and separated by $2 \mathrm{~m}$ buffer. In May of 2017, N and P fertilizers were mixed with soil evenly and spread to the plot surface during rainy days.

\section{Plant and soil sampling and measurements}

Leaf and soil samples were collected in September 10-12, 2017. Mature leaf samples were collected in the center of the subplot $(1 \mathrm{~m} \times 1 \mathrm{~m})$ and dried at $75{ }^{\circ} \mathrm{C}$ for 48 hours after removing impurities. Dried leaves were ground and sieved by $1 \mathrm{~mm}$ mesh for elemental analysis. Leaf $\mathrm{C}$ and leaf $\mathrm{N}$ were determined by a $\mathrm{CN}$ auto-analyzer (Eurovector, Milan, Italy). Leaf P was analyzed by Mo-Sb colorimetric method after persulfate oxidation (Sparks 1996). Leaf C:N, $\mathrm{C}: \mathrm{P}$, and $\mathrm{N}: \mathrm{P}$ ratios were calculated on a mass basis.

Four soil samples were collected from each plot randomly by a $2 \mathrm{~cm}$-diameter soil drilling sampler at $0-10 \mathrm{~cm}$ depth and then combined into one sample. All samples were sieved by $2 \mathrm{~mm}$ mesh to clear roots and debris after being dried at $105{ }^{\circ} \mathrm{C}$ for 48 hours for chemical analyses. Soil available $\mathrm{N}$ concentration was determined on an auto-analyzer (FIAstar 5000, Foss Tecator, Denmark) after extracting by $2 \mathrm{~mol} \mathrm{~L}^{-1} \mathrm{KCl}$ solution. The soil available P of each 
111

treatment was measured via ammonium molybdate method after extraction using $0.5 \mathrm{~mol} \mathrm{~L}^{-1} \mathrm{NaHCO}_{3}$ solution.

\section{Statistics analysis}

One-way ANOVA was used to detect the influences of different $\mathrm{N}$ and $\mathrm{P}$ additions rates on soil inorganic N; soil available P; leaf C, N, and P concentrations; and leaf C:N, C:P, and N:P ratios. General linear regression models were conducted to measure (1) the relationships between leaf $\mathrm{N}$ and leaf $\mathrm{P}$ in $\mathrm{N}$ addition and $\mathrm{P}$ addition treatments; (2) the relationships between leaf $\mathrm{C}, \mathrm{N}$, and $\mathrm{P}$ concentrations and soil inorganic $\mathrm{N}$ and available $\mathrm{P}$ concentrations in $\mathrm{N}$ and $\mathrm{P}$ additions; (3) and the relationships between leaf N:P and soil N:P. Least significant difference method was conducted to test the significant differences among various nutrient addition rates. SPSS 18.0 was used to analyze all statistical data, and the level of $P=0.05$ was set to test the significance.

\section{Results}

\section{Response of Soil inorganic $N$ and available $P$ concentration to nutrient addition}

Soil inorganic $\mathrm{N}$ concentration did not significantly respond to $\mathrm{N}$ addition (Fig. 1a). $\mathrm{N}$ addition decreased soil available $\mathrm{P}$ concentration significantly (Fig. 1b), but there was no significant difference between seven $\mathrm{N}$ addition rates. This finding indicated that different $\mathrm{N}$ addition gradients are not the factor that affect soil inorganic $\mathrm{N}$ and available $\mathrm{P}$ concentration.

$\mathrm{P}$ addition increased soil inorganic $\mathrm{N}$ (Fig. 1c). And significant differences were noted between different $\mathrm{P}$ addition rates. However, only P7 had a significant influence on soil available P concentration, and no obvious difference was observed in P1-P6 (Fig. 1d), suggesting that P addition gradient only influences soil inorganic $\mathrm{N}$ and not available $\mathrm{P}$.

\section{Response of Leaf stoichiometry to nutrient addition}

$\mathrm{N}$ addition increased leaf $\mathrm{C}$ and $\mathrm{N}$ significantly but exerted no effect on leaf $\mathrm{P}$ (Figs. 2a-c). Leaf $\mathrm{C}$ showed no obvious difference between seven $\mathrm{N}$ addition rates. P addition significantly affected leaf $\mathrm{C}$ and P (Figs. 2d and f). And only P6 and $\mathrm{P} 7$ increased leaf $\mathrm{N}$ significantly. Leaf $\mathrm{C}$ and leaf $\mathrm{N}$ also showed no obvious difference between different $\mathrm{P}$ addition rates. Moreover, no relationship was found between leaf $\mathrm{N}$ and leaf $\mathrm{P}$ under the condition of $\mathrm{N}$ addition, but a positive relationship was observed in $\mathrm{P}$ addition treatment (Fig. 4).

Leaf $\mathrm{N}: \mathrm{P}$ ratio was positively related to $\mathrm{N}$ addition gradient overall, but leaf $\mathrm{C}: \mathrm{N}$ ratio decreased with N5-N7 addition. Furthermore, $\mathrm{N}$ addition did not obviously change leaf C:P ratio (Figs. 4a-c). P addition decreased leaf C:P and N:P ratios significantly. Obvious negative relationships were found between the two ratios and $\mathrm{P}$ addition gradient. Significant differences were also noted among seven P addition rates. However, only P7 decreased leaf C:N ratio; other rates did not have any influence on this ratio. In addition, although $\mathrm{N}$ addition increased leaf N:P ratio and $\mathrm{P}$ addition decreased it, the ratio was always lower than 16 in all treatments.

\section{Relationship of nutrient characteristics between soil and plant}

In $\mathrm{N}$ addition treatments, leaf $\mathrm{C}$ had a significant and positive relationship with soil inorganic $\mathrm{N}$ and a negative 
relationship with soil available $\mathrm{P}$ (Figs.5a and d). Leaf $\mathrm{N}$ exhibited negative relationships with soil available $\mathrm{P}$, but it had no relation to inorganic $\mathrm{N}$ (Figs. $5 \mathrm{~b}$ and e). Leaf $\mathrm{P}$ showed no relationship with either soil inorganic $\mathrm{N}$ or available $\mathrm{P}$ (Figs. 5c and f). In $\mathrm{P}$ addition treatments, leaf $\mathrm{P}$ had significant and positive relationships with soil inorganic $\mathrm{N}$ and available P (Figs. $6 \mathrm{c}$ and f). And there was no correlation between leaf $\mathrm{C}$, leaf $\mathrm{N}$, and soil nutrient concentration (Figs. $6 \mathrm{a}, \mathrm{b}, \mathrm{d}$, and e). In addition, leaf N:P ratio was positively correlated with soil N:P in P addition treatments but was not correlated in $\mathrm{N}$ addition treatments (Fig. 7).

\section{Discussion:}

Alpine grassland is commonly regarded as being limited by $\mathrm{N}$ or co-limited by $\mathrm{N}$ and $\mathrm{P}$. The findings in this study exhibited that the alpine ecosystem more limited by $\mathrm{P}$ addition than $\mathrm{N}$ addition. Furthermore, $\mathrm{N}$ and $\mathrm{P}$ were tightly linked when responding to $\mathrm{P}$ addition but not to $\mathrm{N}$ addition.

\section{Effects of nutrient addition on soil and plant nutrient concentration}

Consistent with the hypotheses in this study, $\mathrm{N}$ addition increased leaf $\mathrm{C}$ and leaf $\mathrm{N}$ concentrations, also consistent with the previous findings that showed $\mathrm{N}$ addition improved $\mathrm{N}$ concentrations in leaf and soil and enhanced the ability of C fixation (Deng et al., 2017; Phoenix et al., 2004). However, different to the hypothesis that soil and leaf nutrients will increase with nutrient addition, the results in the present study showed that $\mathrm{N}$ addition had a negative effect on soil available $\mathrm{P}$ and a neutral effect on soil inorganic $\mathrm{N}$ and leaf $\mathrm{P}$. That similar to the study of Yang et al. (2018) which suggested that $\mathrm{N}$ addition have no influence on soil $\mathrm{N}$ in $\mathrm{N}$-saturated ecosystem. And although $\mathrm{N}$ addition promoted plant growth, no nutrient dilution effect was observed on leaf $\mathrm{P}$. The results suggested that grass could adjust the biochemical characteristics to maintain leaf nutrient stability, similar to the study of Phuyal et al. (2008), who demonstrated that plants could not downregulate or even increase $\mathrm{P}$ uptake ability to maintain leaf $\mathrm{P}$ concentration to respond to increasing biomass with $\mathrm{N}$ addition in no $\mathrm{N}$-limited ecosystem. The possible reason for the reduction in soil available $\mathrm{P}$ with $\mathrm{N}$ addition may be that $\mathrm{N}$ addition increased the $\mathrm{P}$ requirement of plant with the promotion of plant growth (Lu et al., 2018). In addition, the lower $\mathrm{P}$ input in natural conditions, the greater $\mathrm{P}$ uptake ability of plants, and the sequestration of litter are the reasons for the significant decrease in soil available P (Deng et al.;2018; Vitousek et al., 2010).

Contrary to the previous studies that showed soil and leaf nutrient concentrations varied with nutrient addition rates (Lü et al., 2013; Yang et al., 2018), the results of the present study showed that soil and leaf nutrient concentrations had no obvious trend with increasing $\mathrm{N}$ addition rates. These neutral effects might caused by the concentration of soil inorganic $\mathrm{N}$ in $\mathrm{N} 1$ treatment were sufficient to support plant growth, and soil $\mathrm{P}$ was the major limiting factor that restricts plant growth rather than $\mathrm{N}$ (Deng et al., 2017). The findings were also supported by the results of the relationships between leaf and soil nutrient concentrations through general linear regression analysis. Leaf $\mathrm{C}$ and leaf $\mathrm{N}$ exhibited a negative and significant relationship with soil available $\mathrm{P}$. Leaf $\mathrm{N}$ showed no relationship with soil inorganic $\mathrm{N}$ in $\mathrm{N}$ addition treatments, thereby confirming that plant growth is mainly limited by soil available $\mathrm{P}$.

$\mathrm{P}$ addition increased leaf $\mathrm{C}, \mathrm{N}$, and $\mathrm{P}$ and soil inorganic $\mathrm{N}$ concentrations, similar to previous studies that showed $\mathrm{P}$ addition increased the nutrient concentrations of leaf and soil in P-limited ecosystem (Li et al., 2016; Yuan and Chen 2015). In contrast to the general conclusion that soil P availability could improve with increasing P addition in P- 
limited ecosystems (Menge and Field 2007; Xu and Timmer, 1999), the data in the present study showed that soil available $\mathrm{P}$ had no significant difference between $\mathrm{CK}$ and different $\mathrm{P}$ addition rates except $\mathrm{P} 7$ treatment. Even though significant differences were found in leaf $\mathrm{P}$ among the seven $\mathrm{P}$ addition rates, a positive and significant relationship was observed between leaf $\mathrm{P}$ and soil available $\mathrm{P}$ concentration in $\mathrm{P}$ addition treatments. Thus, S. rhodanthum could absorb P from soil indirectly and quickly. The extra P content of P1-P6 treatments was mainly used to support the high P demand induced by the promotion of plant growth and grazing (Medina et al., 2012; Phoenix et al., 2004). The addition of P7 was too much for plant growth, and it could conserve P in soil (Deng et al., 2017). Moreover, the results of the experiments in the present study showed that leaf $\mathrm{N}$ was not correlated with leaf $\mathrm{P}$ when responding to $\mathrm{N}$ addition but significantly correlated to leaf $\mathrm{P}$ in the $\mathrm{P}$ addition treatments. These results were also similar to those of studies that showed plants respond to nutrient addition in N-saturated ecosystems (Yang et al., 2018; Huang et al., 2016).

\section{Effect of nutrient addition on leaf stoichiometric ratio}

In this study, $\mathrm{N}$ addition exerted a negative and significant effect on leaf $\mathrm{C}: \mathrm{N}$ ratio but had no effect on $\mathrm{C}: \mathrm{P}$ ratio. Leaf $\mathrm{C}: \mathrm{N}$ and $\mathrm{C}: \mathrm{P}$ ratios decreased with increasing $\mathrm{P}$ addition gradient. These results suggested that $S$. rhodanthum has dissonant $\mathrm{N}$ and $\mathrm{P}$ use strategies in different nutrient addition condition. And this finding was similar to the conclusion, which has been accepted widely, that nutrient use strategy varies with different soil nutrient-limitation types (Yuan and Chen 2009; Sterner and Elser 2002). The change in leaf C:N and C:P ratios could influence the C:N and C:P ratios of soil through changing the decomposition rates of litter and microbial community composition in general (Güsewell and Gessner 2009; Chapin et al., 2002). Zhang et al. (2018) reported that the increasing N concentration in soil and leaf could accelerate litter decomposition and influence the $\mathrm{N}$ cycling between soil and plant. Some studies also that reported that $\mathrm{N}$ addition could affect soil properties, such as $\mathrm{pH}$, in long-term external experiments and excessive $\mathrm{P}$ addition could increase soil $\mathrm{pH}$ and then change the strategy of plant nutrient use (Zhang et al., 2008; Hinsinger 2001; Lu et al., 2018; Yang et al., 2018). Therefore, the change in leaf C:N:P ratio could have some profound influences on plant nutrient use strategy and then influence this ecosystem with imbalanced $\mathrm{N}$ and $\mathrm{P}$ input over a long period of time.

The N:P ratio $<14$, which means the ecosystem is limited by N, and the ratio $>16$, which means it is limited by $\mathrm{P}$, have been generally shown (Koerselman, and Meuleman 1996). Many studies reported that the threshold of the ratio to indicate ecosystem limitation was not uniform, which depended on plant species and ecosystem types (Güsewell, 2004; Chen et al., 2015). In the present study, the N:P ratio in CK treatment was approximately 12 . In N addition treatments, a positive and significant relationship was found between the ratio and $\mathrm{N}$ addition rates, and the N:P ratio was always below 16 in the $\mathrm{N}$ addition treatments. P addition decreased leaf N:P ratio from 12 in CK treatment to 7 in P7 treatment, and the ratio had a negative and significant relationship with $\mathrm{P}$ addition rates.

The results indicated that external $\mathrm{P}$ addition not only changed the $\mathrm{P}$ concentrations in soil and leaf and the leaf C:P and $\mathrm{N}: \mathrm{P}$ ratios but also influenced soil and leaf $\mathrm{N}$ concentrations and leaf $\mathrm{C}: \mathrm{N}$ ratios. Leaf $\mathrm{P}$ concentration had a positive and significant relationship with leaf $\mathrm{N}$ concentration in $\mathrm{P}$ addition treatments, suggesting that $\mathrm{N}$ and $\mathrm{P}$ were tightly coupled in the soil-plant system under P addition treatment in ecosystems (Elser et al., 2000; Ågren et al., 2012). However, the results in the present study showed no relationship between leaf $N$ and leaf $P$ in $N$ addition treatments. Leaf N:P ratio was positively related to soil N:P ratio in P addition, but it was not sensitive to the ratio in 
$217 \mathrm{~N}$ addition treatments. Furthermore, the extent of change of N:P in P addition was greater than in N addition. These 218 results suggested that $S$. rhodanthum is influenced by $\mathrm{P}$ addition to a greater extent, similar to the studies that leaf 219 nutrient concentration and stoichiometry were more sensitive to $\mathrm{P}$ addition rather than to $\mathrm{N}$ addition in $\mathrm{N}$-saturated ecosystems (Deng et al., 2018; Yang et al., 2018; Chen et al., 2015; Yuan and Chen 2015). Therefore, these results highlighted that $\mathrm{P}$ rather than $\mathrm{N}$ was the major limiting factor in this ecosystem. The plausible reason was that the grassland was limited by $\mathrm{P}$, different from previous studies, which showed that the grassland was mostly limited by $\mathrm{N}$, possibly because long-term imbalanced fertilization increased the soil inorganic $\mathrm{N}$ concentration and then changed the limitation from $\mathrm{N}$ to $\mathrm{P}$ (Lebauer and Treseder 2008; Li et al., 2016). In addition, the threshold of $\mathrm{N}$ and $\mathrm{P}$ limitation was approximately 12 rather than 14 and 16. Thus, the conclusion of Koerselman, and Meuleman (1996) could not be adopted to this alpine grazing grassland, and the understanding of the mechanism of leaf $\mathrm{N}: \mathrm{P}$ ratio response to external nutrient addition in different ecosystems needs further investigation.

\section{Conclusion}

229

230

In conclusion, our results were different to our hypothesizes: 1) $\mathrm{P}$ addition not only increased $\mathrm{P}$ concentration but also changed $\mathrm{N}$ concentrations in soil and leaf. $\mathrm{N}$ addition increased soil inorganic $\mathrm{N}$ and leaf but decreased soil available $\mathrm{P}$ and had no effect on leaf P. External nutrient addition change C:N, C:P, and N:P ratios by altering nutrient concentration in leaf. The varied leaf nutrient characteristics showed that external nutrient addition changes the strategy of nutrient use and would change the rates of nutrient cycling between plant and soil; 2) $\mathrm{N}$ and $\mathrm{P}$ cycling in the soil-plant system were link tightly when respond to external $\mathrm{P}$ addition but independent in $\mathrm{N}$ addition and the plant was more sensitive to $\mathrm{P}$ addition rather than $\mathrm{N}$ addition; 3) This ecosystem is limited by $\mathrm{P}$ rather than $\mathrm{N}$ due to longterm $\mathrm{N}$ deposition and imbalanced fertilization supply. $\mathrm{P}$ addition alleviated $\mathrm{P}$ limitation. In addition, the study we conducted was a short-term and $\mathrm{N}$ and $\mathrm{P}$ alone fertilization experiment, but previous findings showed that the responsive of nutrient addition on the plant was depend on the period of experiment time and there were some differences between N and P addition alone and combined (Clark and Tilman 2008; Li et al.2020; Peng et al. 2019). Therefore, further studies were needed to improve understanding of the effects of long-term and NP combined addition on the nutrient cycle in the soil-plant system.

\section{Funding}

This research was supported by National Natural Science Foundation of China (41807335), Shandong Provincial Natural Science Foundation (ZR2020MC040, ZR2017MC029), the Youth Innovation Promotion Association of the Chinese Academy of Sciences (2020434), the National Postdoctoral Program for Innovative Talents (BX201700279).

\section{References:}

Ågren, G.I., Wetterstedt, J.Å.M., Billberger, M.F.K., 2012. Nutrient limitation on terrestrial plant growth-modeling the interaction between nitrogen and phosphorus. New Phytol. 194, 953-960.

Bennett, E.M., Carpenter, S.R., Caraco, N.F.,2001. Human impact on erodible phosphorus and eutrophication: a global perspective. Bioscience. 51:227-234

Chapin, III, F.S., Matson, P.A., Mooney, H.A., 2002. Principles of Terrestrial Ecosystem Ecology. Springer-Verlag, New York, USA. 
Chen, F., Niklas, K.J., Liu, Y., Fang, X., Wan, S., Wang, H.. 2015. Nitrogen and phosphorus additions alter nutrient dynamics but not resorption efficiencies of Chinese fir leaves and twigs differing in age. Tree Physiology. 35.

Chen, Z.Q., Chen, Z.B., Yan, X.Y., Ba,i L.Y.,2016. Stoichiometric mechanisms of Dicranopteris dichotoma growth and resistance to nutrient limitation in the Zhuxi watershed in the red soil hilly region of China. Plant Soil.398:367-379

Clark, C.M., Tilman, D.,2008. Loss of plant species after chronic low-level nitrogen deposition to prairie grasslands. Nature. 451:712-715.

Deng, M.F., Liu, L.L., Sun, Z.Z., 2016. Increased phosphate uptake but not resorption alleviates phosphorus deficiency induced by nitrogen deposition in temperate Larix principis-rupprechtii plantations. New Phytol. 27400237.

Deng, Q., Hui, D., Dennis, S., Reddy, K.C., 2017.Responses of terrestrial ecosystem phosphorus cycling to nitrogen addition: A meta-analysis. Global Ecol Biogeogr.26:713-728.

Elser, J.J., Sterner, R.W., Gorokhova, E., Fagan, W.F., Markow, T.A., Cotner, J.B., Harrison, J.F., Hobbie, S.E., Odell, G.M., Weider, L.W., 2000. Biological stoichiometry from genes to ecosystems. Ecol. Lett. 3: 540-550.

Fang, S., Yan, J., Che, M., Zhu, Y., Liu, Z., Pei, H., Zhang, H., Xu, G., Lin, X., 2013. Climate change and the ecological responses in Xinjiang, China: model simulations and data analyses. Quatern Int. 311: 108-116.

Fujita, Y., Robroek, B.J.M., de Ruiter, P.C., Heil, G.W., Wassen, M.J., 2010. Increased N affects P uptake of eight grassland species: the role of root surface phosphatase activity. Oikos 119, 1665-1673.

Galloway, J.N., Howarth, R.W., Michaels, A.F., 1996. Nitrogen and phosphorus budgets of the North Atlantic Ocean and its watershed. Biogeochemistry.35:3-25.

Güsewell, S., 2004. N:P ratios in terrestrial plants: variation and functional significance. 164: 243-266.

Güsewell, S., Gessner, M.O., 2009. N:P ratios influence litter decomposition and colonization by fungi and bacteria in microcosms. Funct. Ecol. 23: 211-219.

Hinsinger, P., 2001.Bioavailability of soil inorganic P in the rhizosphereas affected by root-induced chemical changes: a review. Plant Soil. 237:173-195.

Huang, J,, Yu, H., Lin, H.., Zhang, Y,. Searle, E.B., Yuan, Z.,2016. Phosphorus amendment mitigates nitrogen addition-induced phosphorus limitation in two plant species in a desert steppe, China. Plant and Soil. 399:221-232.

Killingbeck, K.T., 1996. Nutrients in senesced leaves: keys to the search for potential resorption and resorption proficiency. Ecology. 77:17161727.

Koerselman, W., Meuleman, A.F., 1996. The vegetation N:P ratio: A new tool to detect the nature of nutrient limitation. Journal of Applied Ecology. 33:1441-1450.

Kozovits, A.R., Bustamante, M.M.C., Garofalo, C.R., Bucci, S., Franco, A.C., Goldstein, G., Meinzer, F.C.,2007. Nutrient resorption and patterns of litter production and decomposition in a Neotropical Savanna. Functional Ecology.21:1034-1043.

Lebauer, D.S., Treseder, K.K., 2008. Nitrogen limitation of net primary productivity in terrestrial ecosystems is globally distributed. Ecology. 89:371-379.

Lebauer, D.S., Treseder, K.K., 2008.Nitrogen limitation of net primary productivity in terrestrial ecosystems is globally distributed. Ecology 89:371-379.

Li, L., Gao, X.P., Li, X.Y., Lin, L.S., Zeng, F.J., Gui, D.W., Lu,Y., 2016a. Nitrogen (N) and phosphorus (P) resorption of two dominant alpine perennial grass species in response to contrasting N and P availability. Environmental and Experimental Botany. 127:37-44.

Li, L., Li, X.Y., Liu, Bo., Lei, J.Q., Yue, Z.W., Li, C.D., 2020. Imbalanced stoichiometric patterns in foliar nutrient resorption response to N and P addition in grazing alpine grassland. Acta Oecologica.102:103505.

Li, Y., Niu, S.L., Yu, G.R., 2016b. Aggravated phosphorus limitation on biomass production under increasing nitrogen loading: a meta-analysis. Glob Change Biol. 22:934-943.

Liu, J., Huang, W., Zhou, G., Zhang, D.Q., Liu, S.Z., Li, Y.Y. ,2012. Nitrogen to phosphorus ratios of tree species in response to elevated carbon 
dioxide and nitrogen addition in subtropical forests. Global Change Biology.19(1):208-216.

Liu, J.X., Huang, W.J., Zhou, G.Y., Zhang, D.Q., Liu, S.Z., Li, Y.Y., 2013. Nitrogen to phosphorus ratios of tree species in response to elevated carbon dioxide and nitrogen addition in subtropical forests. Glob Chang Biol. 19:208-216.

Lu, X.K., Vitousek, P.M., Mao, Q.G., Gilliam F.S., Luo Y.Q., Zhou G.Y., Bai, E., Scanlon, T.M., Hou E.Q., Mo J.M., 2018. Plant acclimation to long-term high nitrogen deposition in an N-rich tropical forest. Proc Natl Acad Sci USA. 115(20): 5187-5192.

Lü, X.T., Reed, S., Yu, Q., He, N.P., Wang, Z.W., Han, X.G., 2013. Convergent responses of nitrogen and phosphorus resorption to nitrogen inputs in a semiarid grassland. Glob Chang. Biol. 19: 2775-2784.

Lü, X.T., Reed, S.C., Yu, Q., Han, X.G., 2016. Nutrient resorption helps drive intra-specific coupling of foliar nitrogen and phosphorus under nutrient-enriched conditions. Plant Soil 398:111-120.

Mackenzie, F.T., Vera, L.M., Lerman, A.,2002. Century scale nitrogen and phosphorus controls of the carbon cycle. Chemical Geology. 190:1332.

Mayor, J.R., Wright, S.J., Turner, B.L., 2014. Species-specific responses of foliar nutrients to long term nitrogen and phosphorus additions in a lowland tropical forest. J Ecol. 102: 36-44.

Medina-Roldan E, Paz-Ferreiro J, Bardgett, R.D.,2012. Grazing exclusion affects soil and plant communities, but has no impact on soil carbon storage in an upland grassland. Agric Ecosys Environ. 149:118-123.

Menge, D.N.L., Field, C.B., 2007. Simulated global changes alter phosphorus demand in annual grassland. Global Change Biology, 13: 252-259.

Mo, Q.F., Zou, B., Li, Y.W., Chen, Y., Zhang, W.X., Mao, R., Ding, Y.Z., Wang, J., Lu, X.K., Li, X.B., Tang, J.W., Li, Z.A., Wang, F.M., 2015.Response of plant nutrient stoichiometry to fertilization varied with tissues in a tropical forest. Sci Rep 5.

Oheimb, G.V., Power, S.A., Falk, K., Friedrich, U., Mohamed, A., Krug A., Boschchatzke, N., Härdtle, W., 2010.N:P Ratio and the Nature of Nutrient Limitation in Calluna - Dominated Heathlands. Ecosystems.13(2):317-327.

Peng, Y.F., Peng, Z.P., Zeng, X.T., Houx, III, J.H., 2019. Effects of nitrogen-phosphorus imbalance on plant biomass production: a global perspective. Plant and Soil. 436: 245-252.

Peñuelas, J., Poulter, B., Sardans, J., Ciais, P., van der, Velde, M., Bopp, L., Boucher, O., Godderis, Y., Hinsinger, P., Llusia, J., Nardin, E., Vicca, S., Obersteiner, M., Janssens, I.A., 2013. Human-induced nitrogen phosphorus imbalances alter natural and managed ecosystemsacross the globe. Nat Commun. 4:2934

Peñuelas, J., Sardans, J., Riva-Ubach, A., Janssens, I.A., 2012. The human-induced imbalance between C, N and P in earth's life system. Glob Chang Biol. 18:3-6.

Phoenix, G.K., Booth, R.E., Leake, J.R., Read, D.J.,, Grime, J.P., Lee, J.A., 2004. Simulated pollutant nitrogen deposition increases P demand and enhances root-surface phosphatase activities of three plant functional types in a calcareous grassland. New Phytol. 161: 279-290.

Phuyal, M., Artz, R.R.E., Sheppard, L., Leith, I.D., Johnson, D., 2008. Long-term nitrogen deposition increases phosphorus limitation of bryophytes in an ombrotrophic bog. Plant Ecol. 196: 111-121.

Sardans, J., Rivas-Ubach, A., Peñuelas, J., 2012.The C: N: P stoichiometry of organisms and ecosystems in a changing world: a review and perspectives. Perspect Plant Ecol Evol Syst. 14:33-47.

Song, Z.P., Hou, J.H., 2020. Provenance differences in functional traits and N: P stoichiometry of the leaves and roots of Pinus tabulaeformis seedlings under $\mathrm{N}$ addition.Global Ecology and Conservation 21, e00826.

Sparks, D.,1996. Methods of soil analysis. SSSA and ASA, Madison.

Sterner, R.W., Elser, J.J., 2002. Ecological Stoichiometry: The biology of Elements from Molecules to the Biosphere. Princeton University Press, Princeton.

Tian, D., Du, E.Z., Jiang, L., Ma, S.H., Zeng, W.J., Zou, A.L., Feng, C.Y., Xu, L.C., Xing, A.J., Wang, W., Zheng, C.Y., Ji, C.J., Shen, H.H., Fang, J.Y., 2018. Responses of forest ecosystems to increasing N deposition in China: A critical review. Environmental Pollution 243, 75-86.

Tian, D.S, Niu, S.L., 2015.A global analysis of soil acidification caused by nitrogen addition. Environ Res Lett. 10:024019 
335

336

337

338

339

340

Vitousek, P. M., Porder, S., Houlton, B. Z., Chadwick, O. A., 2010. Terrestrial phosphorus limitation: Mechanisms, implications, and nitrogenphosphorus interactions. Ecological Applications. 20:5-15.

Wang, R., Balkanski, Y., Boucher, O., Ciais, P., Peñuelas, J., Tao, S., 2014. Significant contribution of combustion-related emissions to the atmospheric phosphorus budget. Nat Geosci. 8:48-54.

Wang, X., Guppy, C.N., Watson, L., Sale, P.W.G., Tang. C., 2011. Availability of sparingly soluble phosphorus sources to cotton (Gossypium hirsutumL.), wheat (Triticum aestivum L.) and white lupin (Lupinus albus L.) with different forms of nitrogen as evaluated by a 32P isotopic dilution technique. Plant and Soil. 348(1-2):85-98.

Xu, X., Timmer, V.R., 1999. Growth and nitrogen nutrition of Chinese fir seedlings exposed to nutrient loading and fertilization. Plant Soil. 216: 83-91.

Xu, X., Wanek, W., Zhou, C., Richter, A., Song, M., Cao, G., Ouyang, H., Kuzyakov, Y., 2014. Nutrient limitation of alpine plants: Implications from leaf N:P stoichiometry and leaf $\delta^{15}$ N. J. Plant Nutrient and Soil Science. 177:378-387.

Yang Hao., 2018. Effects of nitrogen and phosphorus addition on leaf nutrient characteristics in a subtropical forest. Trees. 32:383-391.

You, C.M., Wu, F.Z., Yang, W.Q., Xu, Z.F., Tan, B., Yue, K., Ni, X.Y., 2018. Nutrient-limited conditions determine the responses of foliar nitrogen and phosphorus stoichiometry to nitrogen addition: A global meta-analysis. Environmental Pollution 241, 740-749.

Yuan, Z.Y., Chen, H.Y.H., 2009. Global trends in senesced-leaf nitrogen and phosphorus. Glob Ecol Biogeogr. 18:532-542.

Yuan, Z.Y., Chen, H.Y.H., 2015. Negative effects of fertilization on plant nutrient resorption. Ecology. 96: 373-380.

Yue, P., Li, K.H., Gong, Y.M., Hu, Y.K., Mohammat, A., Christie, P., Liu, X.J., 2016. A five-year study of the impact of nitrogen addition on methane uptake in alpine grassland. Scientific Reports. 6:32064.

Zengyan Li, Xirong Qiu, Yu Sun, Sining Liu, Hongling Hu, Jiulong Xie, Gang Chen, Yinlong Xiao, Yi Tang, Lihua Tu,C:N:P stoichiometry responses to 10 years of nitrogen addition differ across soil components and plant organs in a subtropical Pleioblastus amarus forest,Science of The Total Environment,2021,148925,0048-9697.

Zhang, D., Hui, D., Luo, Y., Zhou, G., 2008. Rates of litter decomposition in terrestrial ecosystems: global patterns and controlling factors. J. Plant Ecol. 1:85-93.

Zhang, L.X., Bai, Y.F., Han, X.G., 2003. Application of N:P stoichiometry to ecology studies. Acta Botanica Sinica, China. 2003(09):1009-1018.

Zhang, Q.F., Xie, J.S., Lyu, M., Xiong, D.C., Wang, J., Chen, Y., Li, Y.Q., Yang, Y.S., 2017. Short-term effects of soil warming and nitrogen addition on the N:P stoichiometry of Cunninghamia lanceolata in subtropical regions. Plant and Soil. 411(1-2):395-407.

Zhu, J., Wang, Q., He, N., Smith, M.D., Elser, J.J., Du, J., Yuan, G., Yu, G., Yu, Q., 2016. Imbalanced atmospheric nitrogen and phosphorus depositionsin China: implications for nutrient limitation. Journal of Geophysical Research Biogeosciences.121(6):1605-1616.

Wang Dong, Chi Zhensheng, Yue Benjiang, Huang Xudong, Zhao Jing, Song Hongquan, Yang Zhongling, Miao Renhui, Liu Yanchun, Zhang Yaojun, Miao Yuan, Han Shijie, Liu Yinzhan., 2020. Effects of mowing and nitrogen addition on the ecosystem C and N pools in a temperate steppe: A case study from northern China. Catena. 185: 104332.

Liu Yinzhan, Zhao Cancan, Guo Jingwei, Zhang Luna, Xuan Juan, Chen Anqun, You Cheng ming. 2021. Short-term phosphorus addition augments the effects of nitrogen addition on soil respiration in a typical steppe. Science of the Total Environment, 761: 143211. 
Figure 1

Effects of Nitrogen(N) and Phosphorus(P) addition on soil inorganic $\mathrm{N}$ and available $\mathrm{P}$ concentrations in the alpine grassland.

CK indicate control treatment. N1, N2, N3, N4, N5, N6 and N7 indicate 0.5, 1, 2, 3, 6, 12 and $24 \mathrm{~g} \mathrm{~N} \mathrm{~m}^{-2} \mathrm{yr}^{-1}$. P1, P2, P3, P4, P5, P6, P7 indicate 0.05, 0.1,0.2,0.4,0.8,1.6,3.2 $\mathrm{g} \mathrm{P} \mathrm{m}^{-2} \mathrm{yr}^{-1}$. Different small letter indicates significant difference between treatments $(P<0.05)$.
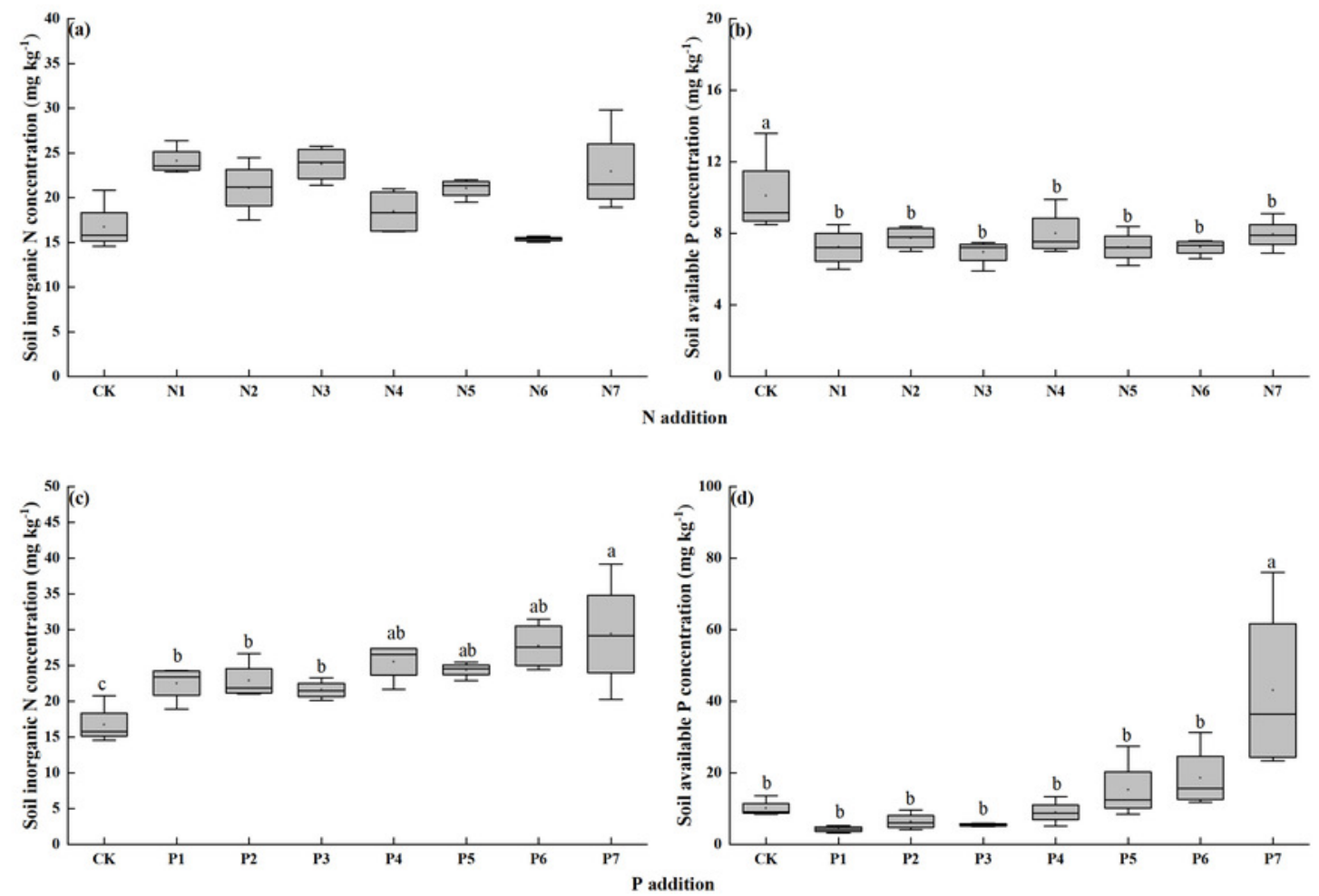
Figure 2

Effects of $\mathrm{N}$ and $\mathrm{P}$ addition on leaf $\mathrm{C} \mathrm{N}$ and $\mathrm{P}$ concentrations of Seriphidium rhodanthum.

CK indicates control treatment. N1, N2, N3, N4, N5, N6 and N7 indicate $0.5,1,2,3,6,12$ and $24 \mathrm{~g} \mathrm{~N} \mathrm{~m}^{-2} \mathrm{yr}^{-1}$, respectively. P1, P2, P3, P4, P5, P6, P7 indicate $0.05,0.1,0.2,0.4,0.8,1.6,3.2 \mathrm{~g}$ $\mathrm{P} \mathrm{m}^{-2} \mathrm{yr}^{-1}$, respectively. Different small letter indicates significant difference between treatments $(P<0.05)$.
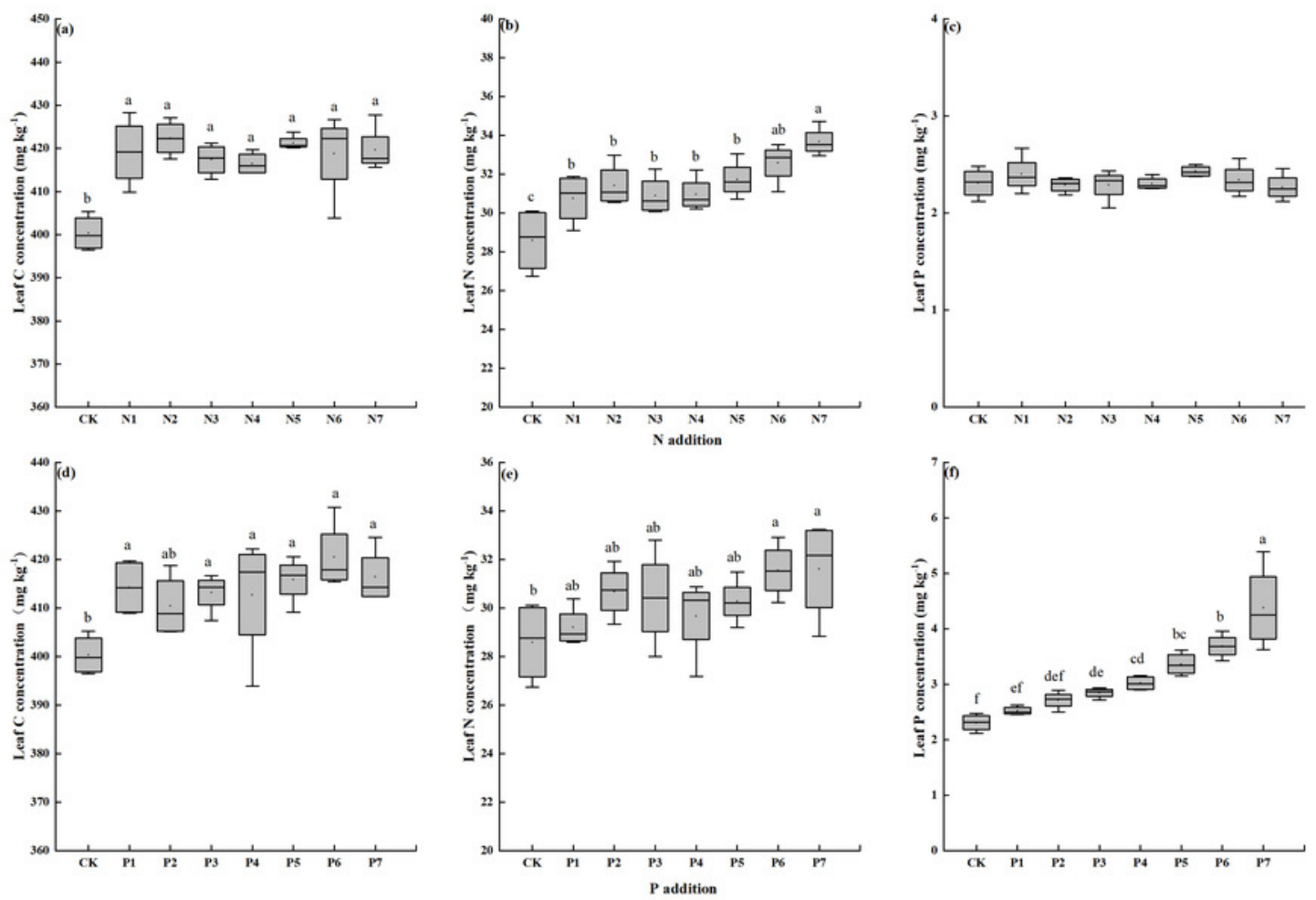
Figure 3

Effects of $N$ and $P$ addition on leaf $C: N, C: P, N: P$ of Seriphidium rhodanthum.

CK indicates control treatment. N1, N2, N3, N4, N5, N6 and N7 indicate $0.5,1,2,3,6,12$ and $24 \mathrm{~g} \mathrm{~N} \mathrm{~m}^{-2} \mathrm{yr}^{-1}$, respectively. P1, P2, P3, P4, P5, P6, P7 indicate $0.05,0.1,0.2,0.4,0.8,1.6,3.2 \mathrm{~g}$ $\mathrm{P} \mathrm{m}^{-2} \mathrm{yr}^{-1}$, respectively. Different small letter indicates significant difference between treatments $(P<0.05)$.
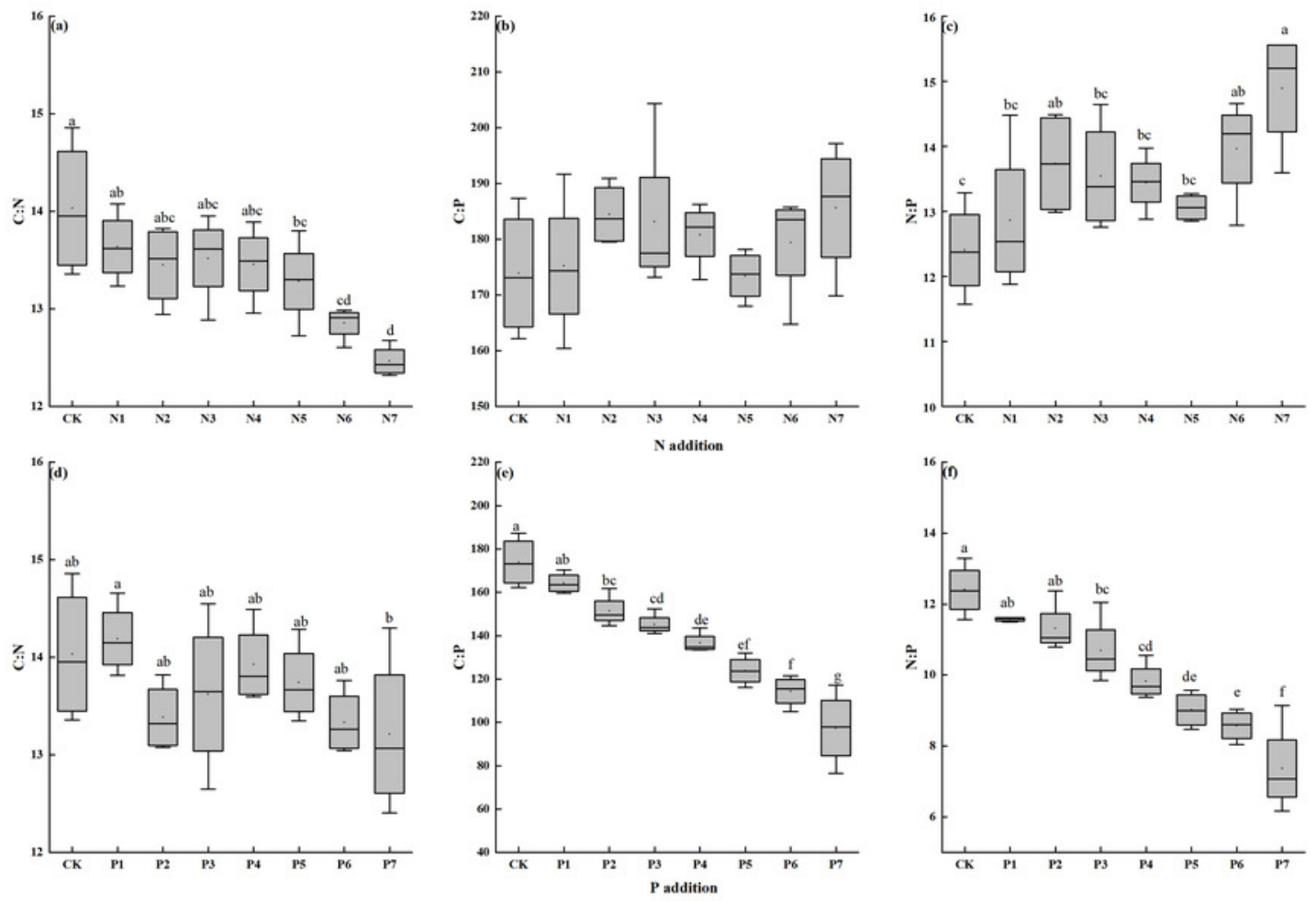
Figure 4

Relationships between leaf $\mathrm{N}$ and leaf $\mathrm{P}$ by by general linear regression analysis.
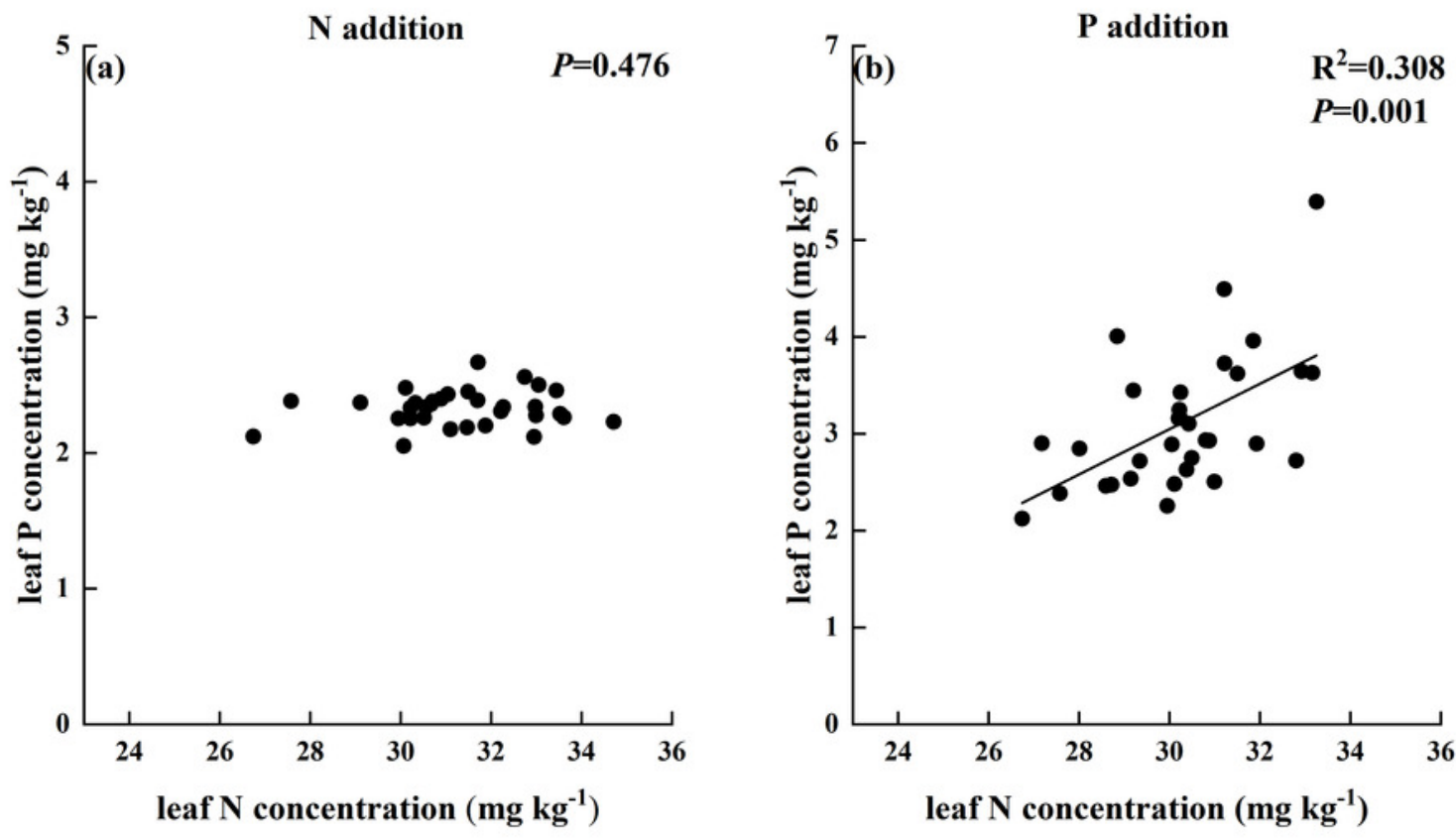
Figure 5

Relationships between leaf $\mathrm{C}, \mathrm{N}, \mathrm{P}$ and soil inorganic $\mathrm{N}$, available $\mathrm{P}$ in $\mathrm{N}$ addition by by general linear regression analysis.
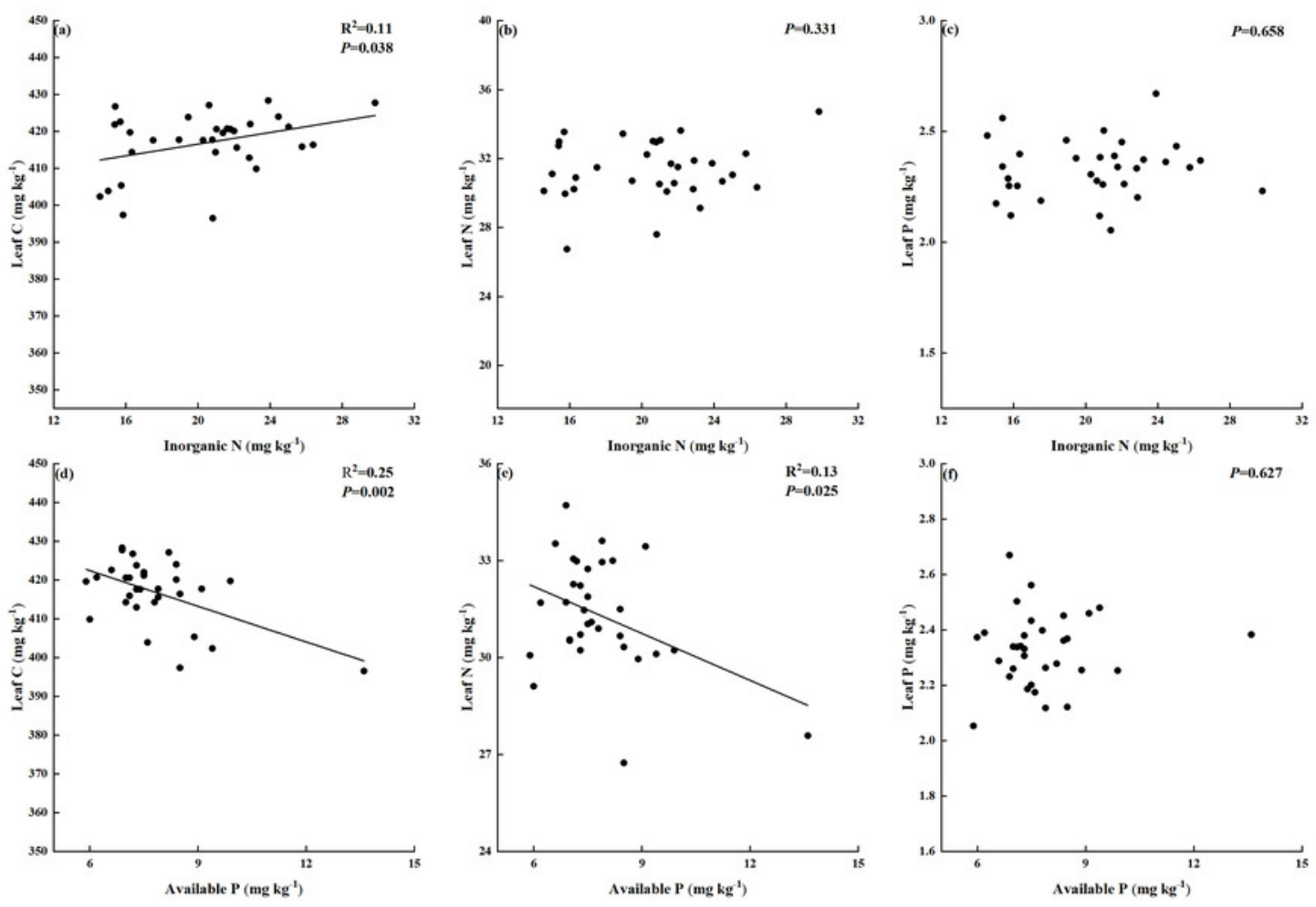
Figure 6

Relationships between leaf $\mathrm{C}, \mathrm{N}, \mathrm{P}$ and soil inorganic $\mathrm{N}$, available $\mathrm{P}$ in $\mathrm{P}$ addition by by general linear regression analysis.
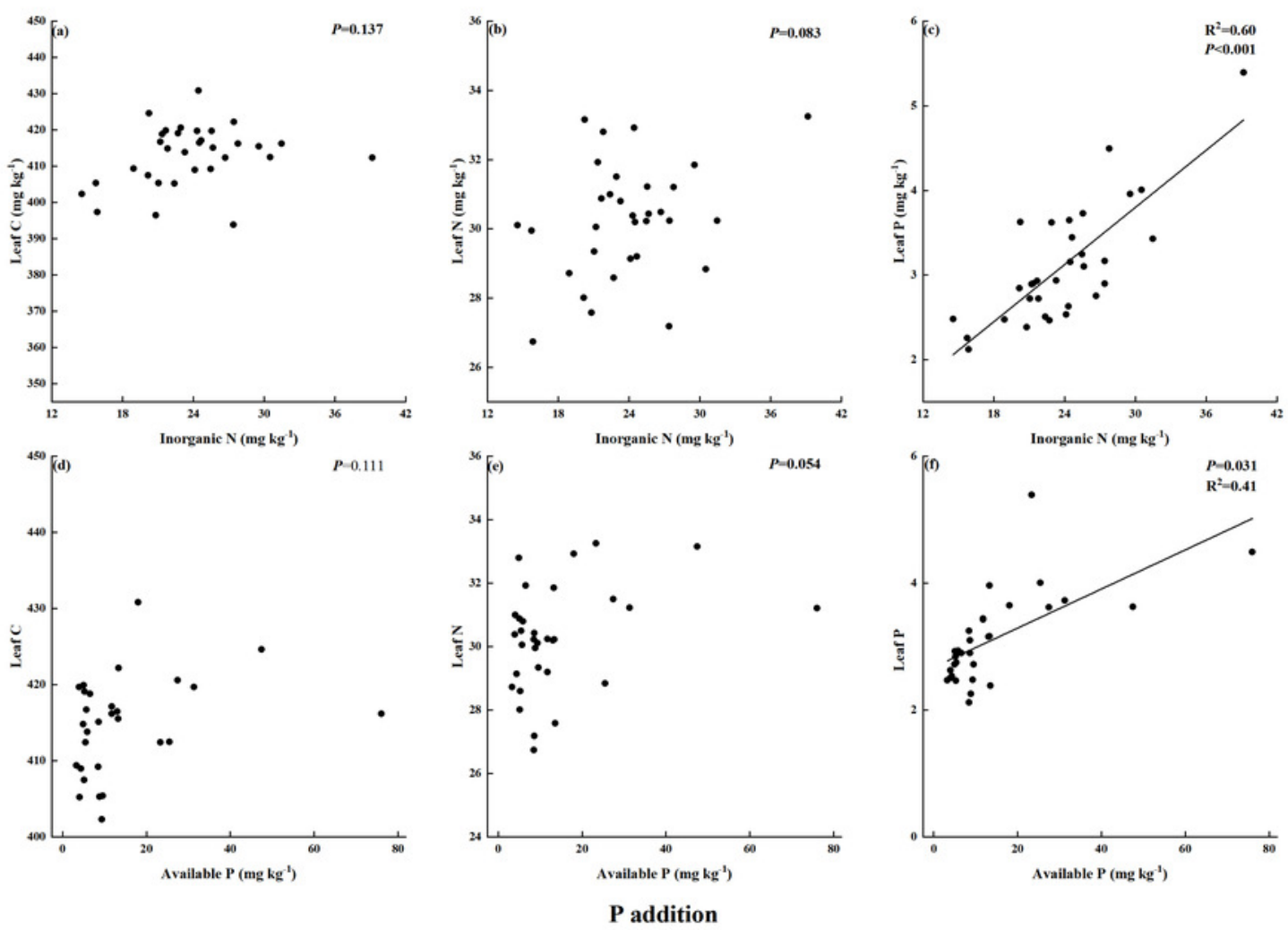
Figure 7

Relationships between soil N:P and leaf N:P in N and P addition by by general linear regression analysis.
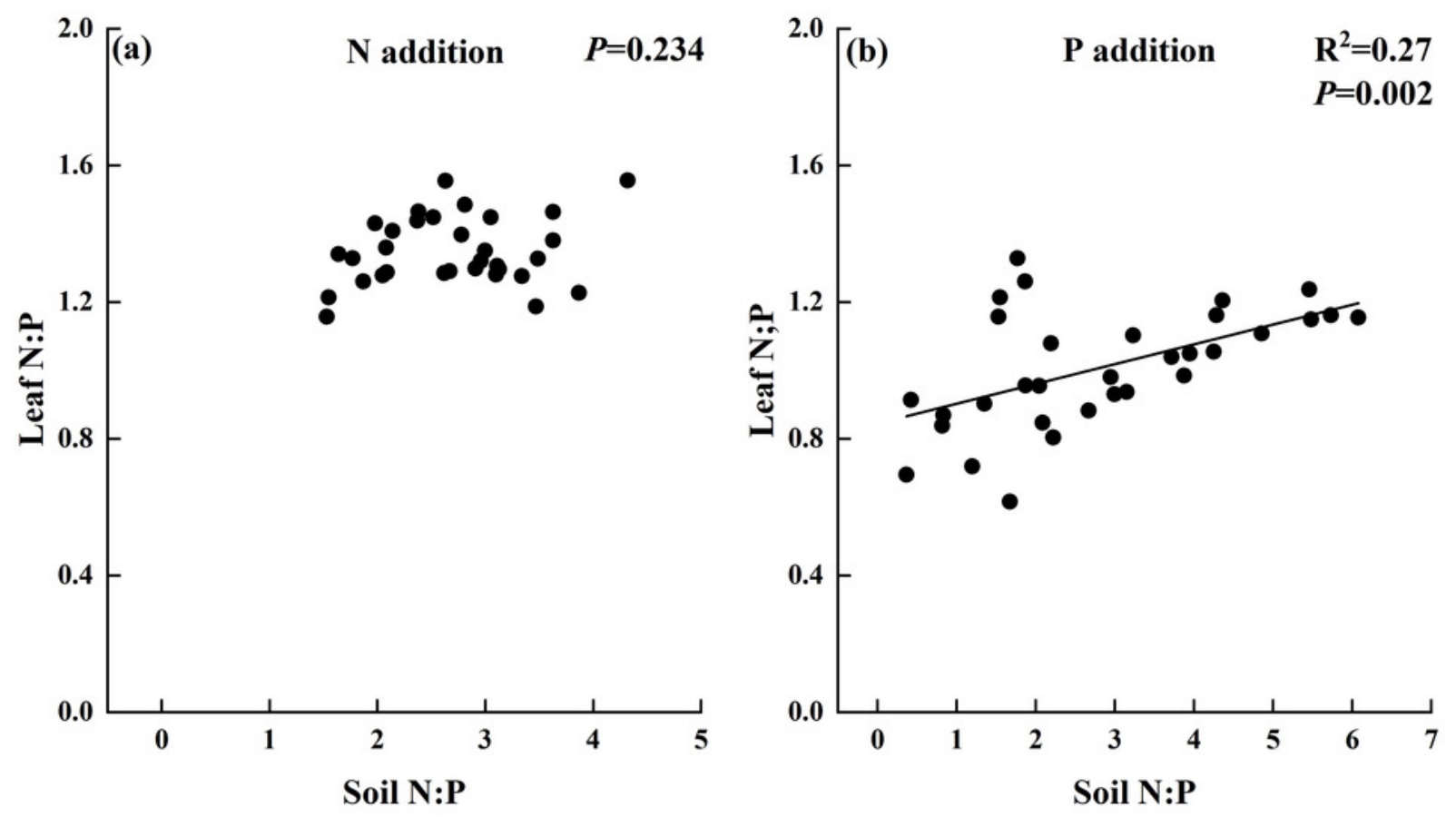